УДК 37.091.32:808.1:159.942-021.414

DOI: 10.37026/2520-6427-2021-108-4-87-91
Володимир ЛАВРЕНЧУК,

кандидат філологічних наук, доиент кафедри суспільно-гуманітарної освіти Рівненського обласного інституту післядипломної педагогічної освіти, м. Рівне, Україна

ORCID: 0000-0002-0413-3500

e-mail:v.lavren4@ukr.net

\section{Марія ЛАВРЕНЧУК,} методист кабінету

суспільно-гуманітарних предметів

Рівненського обласного інституту післядипломної педагогічної освіти, м. Рівне, Украӥна

ORCID: 0000-0001-5598-587X

e-mail:marialavren@meta.ua

\title{
ЕМОЦЙНО-ЦІННІСНА СКЛАДОВА КОМПЕТЕНТНІСНОГО УРОКУ ЛІТЕРАТУРИ В НОВІЙ УКРАЇНСЬКІЙ ШКОЛІ
}

\begin{abstract}
Анотація. У статті схарактеризовано актуальні проблеми компетентнісного підходу до навчання учнів літератури в аспекті Нової украӥнської школи, зокрема продемонстровано необхідність виокремлення емочійно-иіннісного компонента у змісті мовно-літературноі освіти. Актуальність та доцільність досліджуваноі проблематики зумовлено необхідністю переходу до нової за змістом і формою украӥнської школи, покликаної формувати насамперед життєві компетентності та систему иінностей здобувачів освіти, на щзо звертається увага і в державних документах про освіту - Законах Украйни «Про освіту» та «Про повну загальну середню освіту», Кониепиії «Нова украӥнська школа», Державному стандарті початкової освіти, Державному
\end{abstract}

стандарті базової загальної середньої освіти.

Визначено, шо ключовим завданням освіти на сучасному етапі трансформації українського суспільства є створення умов для розвитку і самореалізациї кожної особистості. Відповідно головним показником якості освіти є духовний світ особистості дитини, щуо передусім формується в шкільному курсі рідної мови, украӥнської та зарубіжної літератури. Доведено, щчо найважливішим елементом внутрішньої структури особистості, ї̈ духовного світу є ціннісні орієнтації як форма відображення особистісних иінностей.

Ключові слова: емочійно-иіннісний розвиток, ціннісна орієнтація, цінності, емоції, почуття, читацькі емоиії, оцінні судження, емоційний інтелект.

\author{
Volodymyr LAVRENCHUK, \\ Candidate of Philological Sciences, \\ Associate Professor, \\ Department of Social Humanitarian Education, \\ Rivne Regiona Institute \\ of Postgraduate Pedagogical Education, \\ Rivne, Ukraine \\ ORCID: 0000-0002-0413-3500 \\ e-mail:v.lavren4@ukr.net
}

\section{Maria LAVRENCHUK,}

Methodist,

Office of Social and Humanitarian Subject,

Rivne Regional Institute

of Postgraduate Pedagogical Education,

Rivne, Ukraine

ORCID: 0000-0001-5598-587X

e-mail:marialavren@meta.ua

\section{EMOTIONAL AND VALUE COMPONENT OF THE COMPETENCE LESSON OF LITERATURE IN THE ASPECT OF THE NEW UKRAINIAN SCHOOL}

\footnotetext{
Abstract. The article considers topical problems of the competence approach to teaching literature in the aspect of the New Ukrainian School. It has been substantiated

necessity of isolating the emotional and value component in the content of language and literature education. The urgency and expediency of the researched problem are 
conditioned by the need to transform to a New Ukrainian School in terms of content and form, which is primarily designed to form the life competencies and value system of our students. This is aimed at new national documents on education: The Law of Ukraine "On Education», The Law of Ukraine "On General Secondary Education», The State Standard of Primary Education, The State Standard of Basic General Secondary Education.

Bringing up a modern highly educated, patriotic, innovative, comprehensively developed, successful personality is the main goal of modern education. The main task of education at the present moment of transformation of our society is to create conditions for the development and self-realization of each individual as a citizen of Ukraine.

The most important indicator of the quality of education is the spiritual world of a highly-developed personality, which is largely formed during the school course of the native language, also Ukrainian and foreign literature. The most important element of the internal structure of a person, his/her spiritual world are value orientations, as a form of reflection of personal values.

Attention is drawn to the most generalized nature and essence of the concept of "emotional and value component» of the competence lesson of literature. In the research of modern Ukrainian methodologists and scientists, the emotional-value component of the competence approach is considered as the formation of a cross-cutting skill of emotional intelligence.

The aim of the article is the theoretical substantiation of mutual integration of the process of formation of endto-end skill of emotional intelligence and key and subject competencies and approbation in school practice of models of teaching literature for formation of student's values.

Key words: emotional and value development, value orientation, values, emotions, feelings, reader emotions, evaluative judgments, emotional intelligence.

Постановка проблеми. Сучасні виклики та ризики, перед якими опинилася українська освіта, пов'язані насамперед із прискореним прогресом технологій, зі змінами пріоритетів у постіндустріальний період глобалізації, інформатизації та діджиталізації. Саме тому виникає потреба у переході до освітніх парадигм, що пов'язані з ідеями людиноцентризму, ціннісного ставлення до життя, людської автентичності, креативності та творчості.

Актуальність та доцільність досліджуваної проблеми зумовлені передусім необхідністю переходу до нової за змістом і формою української школи, покликаної формувати життєві компетентності та систему цінностей здобувачів освіти. На цьому наголошується і в державних документах про освіту, серед яких Концепція «Нова українська школа» (2016), Закони України «Про освіту» (2017) та «Про повну загальну середню освіту» (2020), Державний стандарт початкової освіти (2018), Державний стандарт базової загальної середньої освіти (2020).

У зв'язку з цим основним завданням сучасної школи є плекання високоосвіченої, патріотичної, інноваційної, всебічно розвиненої, успішної особистості та створення умов для їі розвитку.

Як відомо, важливим показником якості освіти є духовний світ зростаючої особистості, що формується передусім у шкільному курсі рідної мови, української, зарубіжної літератури. Найважливішим елементом внутрішньої структури особи, iї духовного світу є ціннісні орієнтації, як форма відображення особистісних цінностей.

Аналіз наукових досліджень і публікацій. Проблеми духовності, цінностей знайшли відображення у працях багатьох вітчизняних та зарубіжних учених. Означеному питанню присвятили свої дослідження С. Андреєв, І. Бех, Л. Божко, О. Вишневський, С. Гончаренко, 3. Залевська, В. Знаков, В. Кремень, Г. Кузнецова, Г. Максимов, І. Матусевич, П. Моченов, Д. Чернілевський та ін.

Емоційно-ціннісна сфера репрезентована науковими працями таких учених, як I. Бех, А-М. Богосвятська, Б. Браун, Р. Голідей, Д. Гоулман, С. Девід, І. Звєрєва, О. Ісаєва, Л. Коваль, П. Фролов.

У визначенні оптимальних умов формування ціннісних орієнтацій здобувачів освіти базової школи важливе значення мають розробки у контексті сучасних мовознавчих, літературознавчих, філософських та культурологічних концепцій (О. Авраменко, С. Волощук, В. Гладишев, Н. Голуб, О. Глазова, В. Звиняцковський, Ю. Султанов, Б. Шалагінов); інноваційних форм викладання літератури (О. Ісаєва, Ж. Клименко, Л. Мірошниченко, О. Куцевол, О. Ніколенко, В. Гладишев); діалогічної природи взаємодії культур (В. Доманський); технологізованого навчання літературного аналізу (А. Ситченко). Означені теоретичні засади дають змогу розробити ефективну методику формування ціннісних орієнтацій.

Метою роботи $є$ теоретичне обгрунтування та окреслення моделей навчання літератури 3 метою формування ціннісних орієнтирів учнів та реалізації емоційно-ціннісної складової компетентнісного уроку літератури в аспекті Нової української школи.

Виклад основного матеріалу дослідження. Концепція «Нова українська школа» (2016) головною парадигмою сучасної вітчизняної освіти задекларувала компетентнісний підхід до освітнього процесу та наскрізне формування цінностей. Відповідно Державний стандарт базової середньої освіти (2020) мету мовно-літературної освітньої галузі вбачає у розвитку компетентних мовців і читачів із гуманістичним світоглядом, здатних спілкуватися державною мовою, рідною, іноземними мовами 3 метою духовного, культурного й національного самовираження та міжкультурного діалогу, збагаченні емоційно-чуттєвого досвіду та творчої самореалізації, формуванні ціннісних орієнтацій і ставлень.

Проаналізувавши наукові дослідження з означеної проблематики, можемо стверджувати, що емоційно-ціннісний компонент вивчався багатьма вченими, однак процес формування емоційно-ціннісного потенціалу учнів засобами мовно-літературної освіти у Новій українській школі досі залишається не вивченим.

На думку О. Р. Горак, процес формування готовності до здійснення морального вибору та формування цінностей складається із таких структурних компонентів: когнітивного, емоційно-ціннісного та діяльнісного. Емоційно-ціннісний компонент охоплює цінніснозмістову сферу людини, що відображається в культурі загалом і виявляється у здобутках, особистісних новоутвореннях, знаннях, нормах і цінностях, мотивації до самовдосконалення, культурі спілкування, рефлексії, емпатії, толерантності, прагненні до саморозвитку, культурного зростання тощо (Горак, 2015).

Варто зазначити, що психологічними механізмами розвитку мотиваційно-ціннісної сфери особистості $є$ ідентифікація, емоційне обумовлювання, наслідування, 
мотиваційне опосередкування, комфортність, уживання у соціальну роль, підтримання внутрішньої узгодженості поглядів, педагогічні умови, а також методи, форми і засоби поетапного розвитку мотиваційно-ціннісної сфери (Тимощук, 2005).

Щодо емоційно-ціннісної складової компетентнісного уроку літератури в аспекті Нової української школи, то необхідно окреслити такі ії складові:

- емоційно-ціннісний компонент будь-якої компетентності як інтегрованої здатності здобувача освіти;

- емоційно-ціннісна змістова лінія навчання літератури як домінанта змісту літературної освіти;

- емоційний інтелект як наскрізне вміння всіх ключових компетентностей (Державний стандарт базової середньої освіти, 2020).

У зв'язку з цим можемо стверджувати, що емоційно-ціннісна складова $є$ ключем до розв'язання освітніх завдань мовно-літературної галузі. За цієї умови важливо змоделювати емоційно-ціннісні складові компетентнісного уроку літератури відповідно до циклів (адаптаційного (5-6 класи), базового предметного навчання (7-9 класи)), що дають змогу враховувати вікові та індивідуальні особливості розвитку і потреби учнів, а також забезпечувати просування індивідуальними освітніми траєкторіями.

Зважаючи на зазначене вище, виникає необхідність окреслити оптимальну модель компетентнісного уроку, яку в своїх дослідженнях запропонувала Т. Смагіна (див. рис.) (2012). Дослідниця в структурі уроку пропонує виокремити шість динамічних полів, до яких віднесено такі: мотиваційне, цілепокладання, змістове, технологічне, емоційне, рефлексивне. Сучасний компетентнісний урок характеризується тим, що вирішує проблему мотивації навчальної діяльності школярів. На такому уроці створюється модель «навчання із захопленням». Це насамперед урок, на якому вчитель уміло використовує всі можливості для розвитку особистості учня, iï активного розумового зростання, глибокого і осмисленого засвоєння знань, формування компетентної особистості. Методична структура уроку, на відміну від дидактичної, є змінною величиною.

Важливо зазначити, що у ході компетентнісно орієнтованого уроку важливо враховувати інтереси і потреби учнів, розвивати їхню мотиваційну та емоційну сфери. Вчителю потрібно структурувати свою діяльність відповідно до мотиваційної діяльності учнів, що включає всі види спонукань: мотиви, потреби, інтереси, цілі, прагнення, мотиваційні установки або диспозиції, ідеали та ін.
Окреслюючи структуру компетентності, Т. Смагіна виокремлює такі їі складові: когнітивну, емоційно-ціннісну (ставлення - мотивація), діяльнісну. Отже, термін «емоційно-ціннісна складова» інтегрується 3 поняттям «мотивація», що, на нашу думку, є досить слушним.

Емоційне поле, за твердженням більшості дослідників, відповідає за стан особистості, її задоволення та незадоволення собою, власними діями і ставленнями. Функціями емоційної складової освітнього процесу $є$ емоціогенна (поліпшення настрою, пробудження інтересу до навчальної діяльності та пізнання навчального предмета); діагностична (розкриття власних резервів внутрішньої активності, можливість самовираження і самопізнання); релаксаційна (зняття або зменшення тривожності, фізичного та інтелектуального напруження, відновлення внутрішніх сил і резервів); терапевтична (корекція взаємовідносин, подолання труднощів у поведінці, навчанні, що виникли або виникають у школярів у спілкуванні з однокласниками, вчителями тощо). Як елемент педагогічного супроводу освітнього процесу емоційний компонент передбачає реалізацію цілеспрямованого емоційного впливу на школярів із метою розвитку певних особистісних якостей та формування позитивного ставлення до навчальної діяльності.

Окреслимо модель емоційно-ціннісної складової компетентнісного уроку відповідно до зазначених Державним стандартом базової середньої освіти (2020) циклів: адаптаційного (5-6 класи) та базового предметного навчання (7-9 класи).

Модель емочіийно-ціннісної складової

компетентнісного уроку літератури адаптаційного ициклу (5-6 класи)

Під час адаптаційного періоду навчання літератури (5-6 класи) в умовах Нової української школи варто розпочати із розвитку і керування емоціями й емоційними станами. За цієї умови слід пам'ятати, що емоція - це реакція людини на внутрішні та зовнішні подразники, що мають яскраво виражене суб'єктивне забарвлення й охоплюють усі види почуттєвості та переживання. Відповідно почуття - це специфічні узагальнені людські переживання, ставлення до людських потреб, задоволення або незадоволення яких викликає позитивні або негативні емоції - радість, любов, гордість або сум, гнів, сором тощо (Педагогічний словник, 2001).

Емоції, на відміну від почуттів, виникають не до когось чи чогось, а відповідно до ситуації загалом.

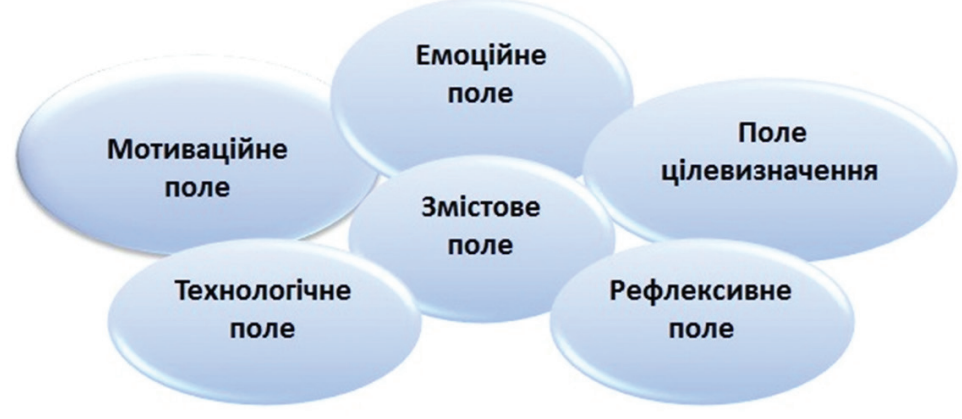

Рис. «Поля компетентнісного уроку» (за Т. Смагіною) 
Переживання емоційних станів (радості, любові, дружби, симпатії, прихильності або болю, суму, страху, ненависті, презирства, огиди тощо) завжди супроводжується відповідними зовнішніми або внутрішніми проявами. Зовнішні прояви емоцій та почуттів проявляються через рухи, міміку, інтонацію під час мовлення, погляд тощо, тоді як внутрішні - через серцебиття, дихання та ін.

Згідно з означеною моделлю обов'язковими результатами навчання є здатність регулювати власний емоційний стан, що трансформуються у конкретні результати навчання: здатність учня пояснювати емоційний стан (свій та інших осіб); розповідати про власний емоційний стан, описуючи окремі відтінки настрою, почуттів, переживань тощо під час рефлексії власної діяльності або сприймання повідомлення (зокрема художнього тексту, медіатексту); збагачувати естетичний та емоційно-чуттєвий досвід; аналізувати емоційний стан літературних персонажів, їх вчинки для моделювання власної поведінки та формування базових морально-етичних норм, виявляючи толерантність; характеризувати емоційний стан літературних персонажів, їх поведінку та вчинки, виявляючи толерантність; проводити паралелі між образами і ситуаціями, зображеними в тексті (Державний стандарт базової загальної середньої освіти, 2020).

Ціннісний компонент моделі представлений загальними результатами навчання (оцінює усну інформацію), що трансформуються у конкретні результати здобувача освіти: висловлює своє ставлення до змісту та форми почутого повідомлення (невеликого художнього тексту, медіатексту або уривка 3 нього) за умови чіткого нормативного мовлення; визначає повноту інформації, у разі потреби звертаючись до відповідних джерел, доречно цитуючи окремі невеликі фрагменти почутого повідомлення; характеризує з використанням типових мовленнєвих засобів почуте повідомлення з позицій основних правил спілкування, дотримується їх (Державний стандарт базової загальної середньої освіти, 2020).

Модель емоційно-ціннісного компонента компетентнісного уроку у період базового предметного навчання (7-9 класи)

Обов'язкові загальні результати навчання щодо ціннісних ставлень трансформуються у здатність учнів пояснювати естетичну та мистецьку цінність прочитаних текстів (художніх текстів, медіатекстів) у культурно-історичному контексті; обгрунтовувати думку щодо естетичної та мистецької цінності прочитаних текстів у культурно-історичному контексті 3 урахуванням взаємозв'язків української та інших національних культур; встановлювати значення прочитаного в кількох текстах для досягнення визначеної мети діяльності; з'ясовувати важливість і прогнозувати доцільність подальшого використання інформації, здобутої із кількох текстів, з урахуванням прочитаного; визначати якість і достовірність інформації на основі власного досвіду, критично сприймаючи думки інших осіб; аргументовано висловлюватися про актуальність і достовірність інформації на основі власного досвіду, аналізу прочитаного тексту та критичних суджень інших осіб; робити аргументовані висновки про наявність у тексті ознак маніпулятивного впливу, доречно цитуючи відповідні фрагменти (Державний стандарт базової середньої освіти, 2020).

Емоційна складова, представлена загальним результатом навчання (регулює власний емоційний стан) і трансформується у здатність учнів аналізувати і враховувати різні емоційні реакції (свої та інших осіб) для ефективного спілкування, керувати власними емоціями в типових ситуаціях спілкування, здійснювати позитивний вплив на емоційний стан співрозмовників для досягнення мети спілкування; характеризувати міжособистісні взаємодії в почутому повідомленні, зокрема художньому тексті, медіатексті, вказуючи на розмаїття емоційних станів і пояснюючи їх для розвитку власного емоційного інтелекту (Державний стандарт базової середньої освіти, 2020).

Таким чином, ми розглянули моделі компетентнісного уроку літератури в контексті емоційно-ціннісного підходу та емоційно-ціннісної складової освітнього процесу в Новій українській школі. Переконані, що виокремлення емоційно-ціннісної складової сприятиме формуванню ключових компетентностей та наскрізних умінь здобувачів базової середньої освіти, підсилить їхню мотивацію до навчальної діяльності.

Висновки. Зважаючи на викладене нами у статті, можемо зробити висновок, що емоційно-ціннісна складова компетентнісного уроку літератури Нової української школи є багатоаспектною й інтегрується на всіх рівнях компетентнісної парадигми освітнього процесу, починаючи від рівня структури компетентності (когнітивний, емоційно-ціннісний, діяльнісний компоненти), структури компетентнісного уроку літератури (мотиваційне поле, емоційне поле, рефлексивне поле) та завершуючи результатом і головною метою освітнього процесу, базового компонента мовно-літературної галузі Державного стандарту базової середньої освіти (2020), пов'язаних із наскрізним формуванням цінностей та емоційного інтелекту.

Перспективи подальших досліджень убачаємо в розробці практичних моделей компетентнісного уроку літератури у базовій та старшій (профільній) школі 3 урахуванням емоційно-ціннісного підходу.

\section{СПИСОК ВИКОРИСТАНОЇ ЛІТЕРАТУРИ}

Нова українська школа. Концептуальні засади реформування середньої школи. (2016). URL: https:// www.kmu.gov.ua/storage/app/media/reforms/ukrainskashkola-compressed.pdf (дата звернення: 10.09.2021).

Державний стандарт базової середньої освіти від 30.09.2020 p. № 898. URL: https://www.kmu.gov.ua/ npas/pro-deyaki-pitannya-derzhavnih-standartiv-povnoyizagalnoyi-serednoyi-osviti-i300920-898 (дата звернення: 15.09.2021).

Горак, О. П. (2015). Особливості формування готовності до здійснення морального вибору у проблемних ситуаціях: емоційно-ціннісний компонент. Молодий вчений. № 12. Ч. 3. С. 121-124.

Тимощук, I. В. (2005). Педагогічні умови виховання у студентів медичного технікуму гуманістичних цінностей: автореф. дис... канд. пед. наук. Тернопіль: Терноп. нац. пед. ун-т ім. В. Гнатюка. 20 с.

Смагіна Т. М. Теоретичні та практичні основи конструювання компетентнісного уроку. (2012). Вісник Житомирського державного університету імені Івана Франка. Вип. 61. С. 128-131. URL: http://nbuv.gov.ua/ UJRN/VZhDU_2012_61_26

\section{REFERENCES}

Nova ukrainska shkola. Kontseptualni zasady reformuvannia serednoi shkoly [New Ukrainian school. Conceptual principles of secondary school reform]. (2016). 
URL: https://www.kmu.gov.ua/storage/app/media/reforms/ukrainska-shkola-compressed.pdf (data zvernennia: 10.09.2021). [in Ukrainian].

Derzhavnyi standart bazovoi serednoi osvity vid 30.09.2020 r. № 898 [State standard of basic secondary education. Resolution of the Cabinet of Ministers of Ukraine]. URL: https://www.kmu.gov.ua/npas/pro-deyaki-pitannya-derzhavnih-standartiv-povnoyi-zagalnoyi-serednoyi-osviti-i300920-898 (data zvernennia: 15.09.2021). [in Ukrainian].

Horak, O. P. (2015). Osoblyvosti formuvannia hotovnosti do zdiisnennia moralnoho vyboru u problemnykh sytuatsiiakh: emotsiino-tsinnisnyi komponent [State standard of basic secondary education. Resolution of the Cabinet of Ministers of Ukraine]. Molodyi vchenyi. № 12. Ch. 3. S. 121-124. [in Ukrainian].
Tymoshchuk, I. V. (2005). Pedahohichni umovy vykhovannia u studentiv medychnoho tekhnikumu humanistychnykh tsinnostei [Pedagogical conditions of education of students of medical technical school of humanistic values]: avtoref. dys... kand. ped. nauk. Ternopil: Ternop. nats. ped. un-t im. V. Hnatiuka. 20 s. [in Ukrainian].

Smahina T. M. Teoretychni ta praktychni osnovy konstruiuvannia kompetentnisnoho uroku [Theoretical and practical bases of constructing a competence lesson]. (2012). Visnyk Zhytomyrskoho derzhavnoho universytetu imeni Ivana Franka. Vyp. 61. S. 128-131. URL: http:// nbuv.gov.ua/UJRN/VZhDU_2012_61_26 [in Ukrainian].

Дата надходження до редакиіï: 05.11.2021 p.
УДК [811.161.2:378.016.]:008

DOI: $10.37026 / 2520-6427-2021-108-4-91-98$
Наталія МУШИРОВСБКА, кандидат філологічних наук, доцент кафедри стилістики та культури украӥнської мови Рівненського державного гуманітарного університету, м. Рівне, Украӥна ORCID: 0000-0003-1319-1101 e-mail: nat.mushyrovska@gmail.com

\section{УКРАЇНОЗНАВЧІ ЗАСАДИ ВИКЛАДАННЯ УКРАЇНСЬКОЇ МОВИ ЗА ПРОФЕСІЙНИМ СПРЯМУВАННЯМ СТУДЕНТАМ СПЕЦІАЛЬНОСТІ «КУЛЬТУРОЛОГІЯ»}

Анотація. Стаття присвячена проблемі організаиії мовної професійної підготовки фахівців-культурологів на засадах українознавства на заняттях з украӥнської мови за професійним спрямуванням. У ній здійснена спроба намітити основні шляхи реалізаціі украӥнознавчого підходу для формування мовно-професійних компетентностей здобувачів вищої освіти за фахом «Культурологія», означено роль принципів міжпредметності та текстоиентризму у його застосуванні, щзо передбачає поліфункиіональне використання текстів українознавчої тематики, з'ясовано дидактичні можливості використання украӥнознавчого матеріалу на заняттях з украӥнської мови за професійним спрямуванням, запропоновано можливі види завдань для роботи з текстом украӥнознавчої, соиіокультурної тематики.

У публікаиії розглянуто змістове наповнення дисичилліни в контексті концепиій мовної освіти, завданням яких є розробити технологію формування наџіонально свідомої україномовної особистості, компетентної у низиі аспектів: мовному, мовленнєвому, стратегічному, сочіокультурному, українознавчому. Проаналізовано значимість українознавчого змісту у навчальних матеріалах та підручниках з украӥнської мови за професійним спрямуванням. Звернено увагу на необхідність залучення фактів з історії української мови і культури до освітнього контенту з метою формування мовної $і$ мовленнєвої компетентності, культури мови, виховання історичної пам'яті, національної свідомості і мовної стійкості. Зокрема, в результаті змістового та мовного аналізу украйнознавчого тексту фахівці поглиблюють свої знання інформацією культурологічного змісту, більш глибоко засвоюють національно-культурні компоненти мови, збагачують свій словниковий запас спеціальними лексико-граматичними одинииями. Украӥнознавчий текстовий матеріал мотивує створювати власні тексти культурологічного спрямування, висловлюватися, викладати своє бачення інформації, вступати в дискусію. Моделювання професійних комунікативних ситуацій сприяє набуттю досвіду мовленнєвої діяльності, готовності до ситуативного мовлення, успішної реалізачії комунікативного наміру у професійній діяльності.

Ключові слова: мовна особистість, мовленнєві вміння й навички, міжпредметні зв'язки, етнолінгвіситичний підхід, текстоцентричний підхід, лексико-семантичний підхід. 